\title{
Quality management and international trade: institutionalization of quality standards and performance outcomes in China
}

Yujuan Guo, Abe P. L. Jong and Andy C. L. Yeung ${ }^{*}$

* Correspondence: andy.yeung@ polyu.edu.hk

Department of Logistics and Maritime Studies, The Hong Kong Polytechnic University, Hong Kong, China
Abstract: Although the original purpose for quality management standards such as ISO 9000 was to facilitate international trade, their effectiveness is widely questioned recently. In the literature, it has been commonly argued that institutionalization of quality standards as time goes by is a major reason behind their ineffectiveness. We explored this issue by using recent data from stock-listed firms in China. Following previous studies in this area, we examined the impact of quality management standards on the cost-efficiency and sales performance of adopting firms from 2000 to 2014. We explored if such an impact is contingent on the level of institutionalization as evidenced by the time of certifications. We show that the time of quality certifications in China has a negative impact on the effectiveness of standards in improving costefficiency. However, we did not find a similar weakening impact on sales performance. Overall, we find evidence of the deteriorating effects of quality management certifications in more recent years.

Keywords: Quality management standards, International trade, Cost-efficiency, China

\section{Introduction}

Supply chain transactions have become more complex and international than ever, making it increasingly difficult for buyers to observe and ensure quality sellers (Terlaak and King 2006). The International Organization for Standardization's main objective is to provide a set of harmonized worldwide technical standards in order to facilitate international exchanges and promote global trade (Clougherty and Grajek 2014). In the early years, international standards like ISO 9000 had proven significant in acting as the determinants of international trade, indeed, more than that of national standards (Clougherty and Grajek 2014; Potoski and Prakash 2009). Specifically, the ISO 9000 Quality Assurance Standards were published by the Technical Committee (TC176) of the International Organization for Standardization in 1979 to provide universal quality management standards and to rectify information asymmetry issues in international trade. It has been proven that ISO 9000 can act as an effective driver to increase trade (Potoski and Prakash 2009; Terlaak and King 2006). However, in recent years many experts find that the effectiveness of quality management standards are deteriorating due to a process of institutionalization.

(c) The Author(s). 2018 Open Access This article is distributed under the terms of the Creative Commons Attribution 4.0 International License (http://creativecommons.org/licenses/by/4.0/), which permits unrestricted use, distribution, and reproduction in any medium, provided you give appropriate credit to the original author(s) and the source, provide a link to the Creative Commons license, and indicate if changes were made. 
Although the original idea of quality management standards was to assure customer satisfaction and facilitate international trade, such a purpose can be easily distorted due to institutionalization. Institutionalization refers to a process whereby organizational innovations become more symbolic in their surface value and less substantial in their actual practice (Staw and Epstein 2000). In other words, firms could symbolically adopt quality management standards without really attaching to their principles. We conducted a large-scale longitudinal study based on objective archival data from firms listed in Shanghai and Shenzhen, China. We traced the relevant quality certifications obtained by a firm and the corresponding performance changes in Chinese manufacturing firms in the past 15 years (2000-2014).

A major research gap in the literature is that although it has long been argued that the process of institutionalization (i.e., symbolic adoption to meet regulatory requirements) will significantly weaken the effectiveness of quality management standards in China, there is a lack of objective evidence based on longitudinal data from the country. By tracking the time of firms' quality management certifications over 15 years (from 2000 to 2014) and using objective accounting and financial data from stock listed firms in China, we provide first empirical evidence on the institutionalization of quality standards in the country based on longitudinal analysis of objective data (including sales performance and cost-efficiency). Our contribution to the literature is that our empirical evidence will help explain why the original purpose of quality management standards can be distorted and quality certifications in China can become less effective as time goes by and many firms adopt the standards symbolically rather than substantially.

\section{Quality management standards and international trade}

Before the establishment of the ISO 9000, information asymmetry appeared to be an unrecognized barrier within international trade agreements (Potoski and Prakash 2009). In fact, lack of certainty in the credibility of quality impedes international trade and thus should not be an overlooked issue (Grossman 1981; Lavissiere and Rodrigue 2017; Munim and Schramm 2018). This was especially true for developing countries, where there is often a lack of credible authorities to distinguish higher quality products from lower quality products. More importantly, buyers often associate poor quality of exports with these countries. As a result, firms that are actually capable of producing high quality products find themselves in a weak position when bargaining for a good price (Potoski and Prakash 2009). Quality management standards thereby can be an effective way to ease this information asymmetry issue and to promote the exports of less developed countries (Munim and Schramm 2018; Potoski and Prakash 2009).

According to Anderson et al. (1999), firms implement ISO 9000 for three main reasons: 1) to comply with government regulations, 2) to meet buyers' quality requirements and enhance their confidence and business relationships, and 3) to gain operational efficiency. ISO 9000 has been widely adopted by firms all over the world. To obtain ISO 9000, a firm is required to establish written quality management processes and procedures that specify an internal quality policy and targets along with regular reviews and reports through accredited third-party audits. Firms need to provide training to staff members and designate a quality representative to coordinate the 
implementation of quality management systems. This extensive requirement allows ISO 9000 to be a credible agent to improve a firm's internal quality systems and procedures (Potoski and Prakash 2009).

Quality certifications also allow firms, especially those located in developing countries such as China, to signal to potential international buyers their product quality (Terlaak and King 2006). Identification of high quality sellers has been a central issue surrounding international trade because desirable attributes are often complex and difficult to measure (Munim and Schramm 2018; Terlaak and King 2006). Linguistic and cultural differences further hinder credible international communication and negatively affect the confidence of international buyers, leading to high transaction costs for buyers trying to precisely identify high quality exporters (Hallak 2006; Hummels and Klenow 2005). This is particularly the case for sellers from developing countries who often find themselves at a disadvantage position because buyers often perceive lower quality standards from an generally negative product image in these countries (Hudson and Jones 2003; Tybout 2000). Quality certifications can effectively provide credible signals about product quality from firms in developing countries, enabling international buyers to differentiate between high- and low-quality products from the same country (Potoski and Prakash 2009).

\section{Research hypotheses on the institutionalization of quality certifications in China}

Quality certification programs provide clear specifications, which are available for free, about how to achieve the standards required to be certified. This allows firms that do not have the know-how to achieve the quality level demanded by importers to learn how to enhance their quality without any additional expense. As a result, this leads to accelerating sales growth while fostering trade potential (Potoski and Prakash 2009; Terlaak and King 2006). Like ISO 9000, other quality management standards are essential for international trade. They ease information asymmetries within international trade by providing a credible basis for buyers to identify quality exporters, especially from developing countries. As a result, firms certified for quality management standards should provide a credible signal to their buyers and supply chain partners, facilitating sales growth, particularly from those overseas buyers.

However, as quality management standards are increasingly institutionalized, their effectiveness to facilitate sales performance and international trade also deteriorates and becomes questionable (Staw and Epstein 2000; Yeung et al. 2011). Institutional theory is a widely accepted notion that human's or organizational behaviors are often driven by normative, memetic and coercive forces for seeking legitimacy, leading to isomorphism and rational myths. According to institutional theory, late adopters are often driven by institutional forces (Guler et al. 2002). As firms seek quality certifications for legitimacy purposes only, the actual performance impact is weakened. As a result, the later the certification, the higher the level of institutionalization, and the weaker their effects on sale performance of stock listed firms in China:

Hypothesis 1: The positive impact of quality management certifications on sales performance has deteriorated as standards have been institutionalized in China in recent years. 
Quality management standards provide fundamental guidelines for firms to follow, which allows firms to constantly learn and enhance their standards, and helps them increase their internal efficiency as they work to meet the demands of buyers (Corbett et al. 2005; Yeung et al. 2011). Quality management principles required by the standards provide firms with methods to consistently fulfil process requirements and meet customer demands. The basic principles of quality management, such as customer focus, process approach, continuous operational improvements, and factual approach to decision-making, allow firms to operate more cost-effectively. For example, ISO 9000-certified firms should establish systems, processes, and procedures to continuously reduce mistakes and eliminate process problems, decreasing waste, quality costs and compliance expenses. In theory, quality management certifications should increase the cost-efficiency of a firm (Corbett et al. 2005). However, as quality certifications become more institutionalized and symbolic, firms may only pay attention to the surface value without really following the insightful principles (Boiral 2007). Employees may act superficially to obtain the certificates and not really learn from quality management standards continuously (Guler et al. 2002). As firms are increasingly driven by normative, memetic and coercive pressures for the purpose of legitimacy seeking, the adoption of quality standards becomes rational myths for symbolic value only, not really for quality and efficiency improvements. As a result, the institutionalization of quality management standards can lead to a deteriorating impact on the cost-efficiency of firms in that the later the certifications, the less effective they are.

Hypothesis 2: The positive impact of quality management certifications on cost-efficiency ratio has deteriorated as the standards have been institutionalized in China in recent years.

\section{Methods}

\section{Data collection procedures for quality certificates}

To test the hypotheses elaborated in the previous section, we collected archival data for a number of major quality certificates that are commonly required in the manufacturing industry in China. We focused on the manufacturing firms on the CSI 300 Index. The CSI 300 Index replicates the performance of the top 300 stocks traded in the Shanghai and Shenzhen stock exchanges. Therefore, a sample of the manufacturing firms listed on the CSI 300 is a good way to reflect the adoption of quality management standards in China, particularly for representative large firms. Out of the 300 companies, 175 manufacturing firms are classified as the manufacturing industry in the index.

We collected quality management certifications from a public database (http:// cx.cnca.cn/) issued by the Certification and Accreditation Administration of the People's Republic of China. The platform provides credible and accurate certificate information for each firm. This database records various kinds of certificates, including Quality Management, Environmental Management, Occupational Health and Safety Assessment Series, and any other certificates companies received. We focused on four quality management certificates: ISO 9000, ISO/TS 16949, ISO 13485, and TL-9000. We looked into the related plants under a parent company to verify whether they obtained the related quality management certificates. To measure the institutionalization level of ISO 9000 certification, we marked down the earliest year of 
the plant's quality management certificate. Of the 175 manufacturing firms in CSI 300, 107 firms obtained ISO 9000, 16 firms obtained ISO/TS 16949, three firms obtained TL-9000, and one firm obtained ISO 13485 over a 15-year period from 2000 to 2014.

In our study, the effectiveness of quality standards is measured by sales performance and cost-efficiency of firms. This is because the original purpose of quality standards such as ISO 9000 was to promote international trades, enhance sales performance of firms, reduce quality issues and make firms more cost efficient. As a result, we believe that both sales performance and cost-efficiency are good indicators for the effectiveness of quality management standards. Sales performance is measured as total revenue from continuous operations of a firm in a certain financial year excluding special items such as sales of assets. Cost efficiency is measured as Cost of Goods Sold (COGS) divided by total sales. Institutionalization is a process whereby an organizational innovation is taken-for-granted and infused with symbolic value without real substance as time goes by. In the literature, it is common to consider that the time of adoption as an indicator of institutionalization (see e.g., Staw and Epstein 2000). Consistent with previous studies, we measure institutionalization by the time of adoption.

\section{Data analysis methods}

We constructed the following multivariate regression model to test our proposed hypotheses:

$$
\begin{aligned}
& Y_{i(t+1)}=\alpha_{0}+\alpha_{1} \text { QM Certificates }_{i t}+\alpha_{2} \text { Recent }_{\text {Years }} \text { Cit } \\
& +\alpha_{3} Q M \text { Certificates }_{i t} \times \text { Recent Years }_{i t}+\text { Controls }_{i t}+\varepsilon_{i t} \text {, }
\end{aligned}
$$

where $i$ and $t$ are firm and year indexes, respectively. $Y$ is sales performance (natural log of sales revenue in US dollars) or cost-efficiency ratio (cost of goods sold divided by sales). Quality Management (QM) Certifications is the total number of quality management certifications of a sample firm in a given year. Recent Years is coded as 1 for years 2007-2014 and 0 for years 2000-2006. We use median split as it is a common way to determine early versus late adopters for an organizational innovation. Controls include firm size (natural log of total assets), firm age (natural log of number of years since IPO), capital slack (sales divided by property, plant, and equipment), debt ratio (total long-term debt divided by total assets), dividend payout (total dividends divided by net income), and industry dummies (binary coding of industries based on China Securities Regulatory Commission's classification). All firm-level variables are measured based on annual accounting data collected from the Compustat Global database. A one-year lag between the dependent and independent variables is maintained to ensure the direction of causality being tested. We rely on $\alpha_{3}$ to determine whether the impact of QM certifications on sales performance $(\mathrm{H} 1)$ or cost-efficiency ratio $(\mathrm{H} 2)$ is more negative in recent years.

\section{Results}

The correlations among all research variables and the multivariate regression results are presented in Tables 1 and 2, respectively. In Table 2, the regression results concerned with sales performance and cost-efficiency ratio are shown in Models 1 and 2, respectively. The number of firm-year observations across the 175 sample firms is 1733 (unbalanced panel). Both models are statistically significant $(p<0.01)$ based on $F$-test. 
Table 1 Correlation matrix

\begin{tabular}{llllllllll}
\hline Variable & 1. & 2. & 3. & 4. & 5. & 6. & 7. & 8. & 9. \\
\hline 1. Sales Performance & 1 & & & & & & & & \\
2. Cost Efficiency & $0.1859^{*}$ & 1 & & & & & & \\
3. QM Certifications & $0.2454^{*}$ & -0.006 & 1 & & & & & \\
4. Recent Years & $0.4029^{*}$ & 0.025 & $0.3047^{*}$ & 1 & & & & \\
5. Firm Size & $0.9069^{*}$ & $0.0794^{*}$ & $0.2035^{*}$ & $0.4451^{*}$ & 1 & & & & \\
6. Firm Age & $0.3204^{*}$ & 0.001 & $0.0651^{*}$ & $0.3485^{*}$ & $0.3644^{*}$ & 1 & & & \\
7. Capital Slack & $0.1256^{*}$ & $0.0752^{*}$ & $0.1656^{*}$ & $0.0867^{*}$ & $-0.0926^{*}$ & 0.029 & 1 & & \\
8. Debt Ratio & $0.2248^{*}$ & 0.015 & $-0.0706^{*}$ & $0.1092^{*}$ & $0.4073^{*}$ & $0.1983^{*}$ & $-0.3636^{*}$ & 1 & \\
9. Dividend Payout & 0.018 & 0.009 & -0.002 & $-0.0721^{*}$ & 0.028 & -0.041 & -0.035 & 0.038 & 1 \\
Mean & 8.678 & 0.632 & 0.411 & 0.597 & 9.012 & 2.053 & 3.148 & 0.089 & 0.242 \\
Standard Deviation & 1.783 & 0.943 & 0.571 & 0.491 & 1.613 & 0.734 & 3.348 & 0.113 & 1.703 \\
\hline
\end{tabular}

${ }^{*} p<0.01$

In Model 1, three controls-firm size, capital slack, and debt ratio-are significant $(p<0.01)$, indicating that firms with larger size, more capital slack, and lower debt ratio have better sales performance. Firm size is a key control variable for sales performance as sales revenue and firm size are highly related. Also, firms with high capital slack are in a better financial position to invest in marketing and promotion activities, which in turn affect sales revenue. Similar, firms with a lower debt ratio are in a better financial position to do so. QM certifications is positive and significant $(p<0.5)$, suggesting that quality certifications improve sales performance. The interaction between QM certifications and Recent Years is negative but not significant $(p>0.5)$. It indicates that there is no difference in sales performance due to quality certifications between recent and early years. $\mathrm{H} 1$ is not supported.

In Model 2, two controls-firm size and capital slack-are positive and significant $(p<0.05)$, indicating that firms with larger size and more capital slack have lower cost-efficiency. One possible explanation is that some large firms in China are state owned and very bureaucratic. From an efficiency point of view, capital slack can be considered as idling resources and may thus make firms less cost efficient (note that a positive significant impact means less efficient). QM certifications is negative and significant $(p<0.01)$, suggesting that $Q M$ certifications reduce cost-efficiency ratio (i.e., improving cost-efficiency). However, the interaction between $Q M$ certifications and Recent Years is positive and significant $(p<0.05)$. It indicates that the impact of $Q M$ certifications on cost-efficiency ratio is more positive (or less negative) in recent years (i.e., less cost reduction upon quality certifications in recent years), supporting $\mathrm{H} 2$. In other words, the improvements in cost-efficiency (or reduction in cost-efficiency ratio) of certified firms deteriorated in recent years.

\section{Discussion and conclusions}

Although previous studies show that institutionalization of quality standards can negatively affect an organization's effectiveness, there is little evidence from China based on longitudinal panel data. Many stock-listed firms in China have a relatively short history, and a well-established dataset from the country was not available in the early years. In particular, some large and comprehensive databases on quality management standards 
Table 2 Multivariate regression results

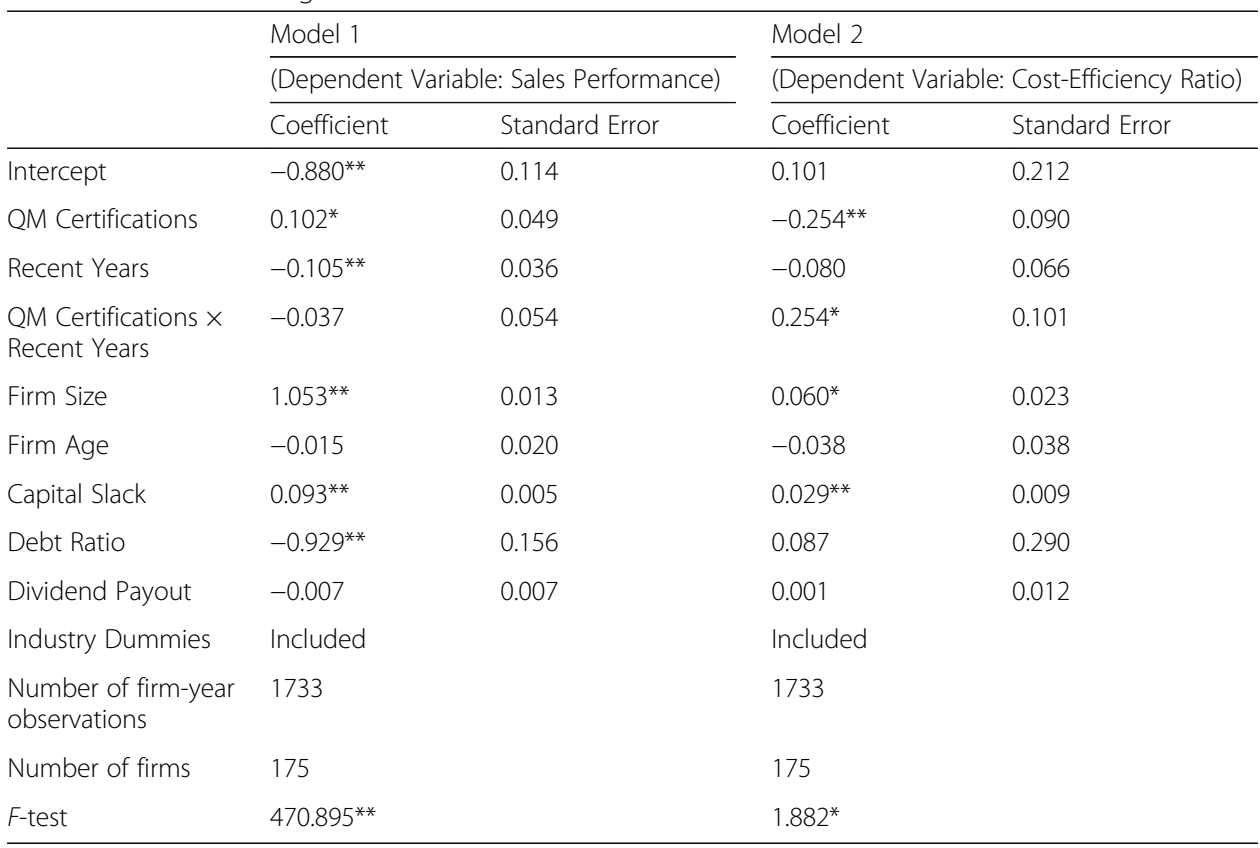

${ }^{*} p<0.05,{ }^{* *} p<0.01$

are now publicly available in the country, facilitating research in this area. In the study, we took advantage of this development and conducted one of the first studies to examine how the value of quality management certifications could deteriorate as time goes by and as the standards are increasingly institutionalized in the country and worldwide.

From the institutional approach, institutional environment has a great influence on the development of organizational structure, often more than that from market pressures. Innovations that enhance technical performance in early-adopting organizations become legitimized in the environment. However, these innovations eventually reach a level of legitimization where they are considered as mandates and create pressures for latecomers to follow. These innovations are merely adopted as symbolic conformity and gestures of compliance (Oliver 1991) to obtain and ensure legitimacy within the institutional environment (Meyer and Rowan 1977). Organizations symbolically adopt measures that are superficially prevalent in their environment, such as job titles, organizational roles, and quality management standards. This legitimacy within the institutional environment often ensures a firm's survival but, unfortunately, hinders firm efficiency and competiveness within the technical environment. To reduce this negative effect, firms often attempt to "decouple" their technical core from legitimizing structures by minimizing evaluations and neglecting program implementation (Meyer \& Rowan, 1977).

In an institutional environment, pressure from larger certified corporations and public institutions obliges organizations to adopt quality management standards such as the ISO 9000. These quality management standards are often institutionalized, which means firms only adopt certain quality management standards ceremoniously without any substantial function and practice. Although the ultimate effect of the institutional environment seems to create homogeneity in organization structures within an institutional environment (DiMaggio and Powell 1983), the extent to how certified firms really practice the standard 
internally is often hard to predict (Brunsson 2000). Despite adopting the same standard, firms can practice the standard in a variety of ways based on their objectives, resources, and needs (Heras-Saizarbitoria and Boiral 2015). Often these standards are merely adopted because of institutional pressures, which fail to bring any substantial change to the firm as time goes by. Firms often decouple their management methods and real practices or needs of their organizations, turning quality management standards into "myths" or "ceremonies." In other words, they are adopted only with the intent to meet the requirements from the external environment without any internal meaning, leading to an organizational hypocrisy (Brunsson 1989). As a result, these quality management standards face a devaluation, where organization actors fail to believe in their real value.

Internationalization leads to an increasing demand for internationally recognized standards. As quality management certifications increasingly become a basic requirement for global trade, many firms are adopting quality standards to meet the demands of international buyers. The number of firms that have adopted ISO 9000 certification has grown exponentially. In 2016, there were over 1.1 million certified organizations worldwide (ISO 2016). The increasing demand for international standards has profound implications for international trade in developing countries like China (Yeung and Mok 2005). ISO 9000 is one of the most commonly required documents for Chinese suppliers. China is also an emerging market with the highest number of ISO 9000 certificates, ranked first in terms of ISO 9000 certifications, with more than 350,000 certified businesses by 2016 (ISO 2016). From an institutional perspective, many of these suppliers do not adopt ISOs to gain cost advantages but to conform to institutional pressures. These firms adopt the ISO certificates to fulfil customer and regulatory requirements for international trade (Yeung and Mok 2005), not really for efficiency in recent years.

One of the major purposes of quality management standards is to assure that the products produced by a supplier will meet the quality requirements of buyers. Quality management standards specify the process requirements of a firm, ensure proper documentations and understanding of customer requirements, and establish quality assurance procedures throughout production processes. Through quality assurance, the standards are supposed to facilitate international trade, particularly for emerging countries such as China. However, as time goes by, the original purpose of quality management standards might deteriorate and distort. ISO 9000 has now become a contractual requirement in international trade. In order to meet the requirement, many firms simply symbolically adopt the standards to meet the requirements of certification bodies without dedicating to their principles. As a result, the monitoring role of certification bodies are increasingly important. Also, rather than focusing on the processes and procedures of quality management, the performance outcomes of these processes and procedures are equally important. As a result, we should shift our focus from process, procedure and documentation requirements of the standards to fact-based performance outcomes in quality and reliability through various outcome-based measures.

\section{Summary and limitations}

International customers are likely to consider quality certificates as an "order qualifier" and select only certified suppliers in developing countries. However, by analyzing 
longitudinal panel data from leading Chinese manufacturing firms listed in Shanghai and Shenzhen, this study shows that quality management standards could be institutionalized as time goes by. Although quality management theory suggests that certified firms should benefit by reducing mistakes and enhancing efficiency through process standardizations and improvements, our empirical results indicate that their positive effect on cost-efficiency could decrease for late adopters in China. Specifically, the positive impact of quality management certifications on cost-efficiency (i.e., cost reductions) could deteriorate as the standards are institutionalized. As more firms obtain the certificates and quality standards are widely promoted, later adopters are under coercive, normative, and mimetic pressures to obtain the certifications without real dedication to their principles. Accordingly, the level of institutionalization could negatively moderate the positive impact on cost-efficiency in early years.

There are some limitations in this study. As the current research focuses only on the leading companies listed in China, we cannot generalize our results to all types of firms. Future research may include small- and medium-sized companies to verify the current findings, although objective accounting figures from these firms are often difficult to obtain. Similarly, we only focused on firms in China. More comprehensive studies based on data in the Western context would also be an interesting direction Lo and Yeung, 2018). In this study, we measure cost-efficiency as the cost of goods sold divided by sales. We realize that the cost of goods sold is influenced by many uncontrollable factors such as fluctuations of raw material prices rather than quality and efficiency management. Future study can be conducted based on other indicators of cost-efficiency. Similarly, we use the year of adoption to measure the institutional level of firms, which is in line with previous research. However, future study can explore other possible measures for the level of institutionalization.

\section{Acknowledgements}

We would like to thank Dr. Hugo Lam from University of Liverpool, UK for his valuable advice and technical assistance in the data analysis of this paper.

Funding

This research was partially supported by Research Grants Council of Hong Kong under PolyU 5518/10H.

Authors' contributions

YG was responsible for data collection, verifications of data and the writing of this paper. APL also took part in the data collection and wrote part of the paper, particularly related to ISO 9000 and International Trade. ACLY was responsible for the conceptual development of this paper and part of the data analysis. All authors read and approved the final manuscript.

\footnotetext{
Authors' information

Yujuan Guo is a Research Associate in the Department of Logistics and Maritime Studies, The Hong Kong Polytechnic University. Her research interest is empirical research in the area of service management and quality management, currently using panel data conducting event studies. She obtained her Master degree (2011) from the Chinese University of Hong Kong and Bachelor degree (2010) from Jinan University, Guangzhou, China.

Abe P. L Jong is a Ph.D. candidate in the Department of Logistics and Maritime Studies, The Hong Kong Polytechnic University. Her research areas are operations management and supply chain management. She received her Bachelor's degree from The Hong Kong Polytechnic University.

Andy C. L. Yeung is currently Chair Professor and Head, Department of Logistics and Maritime Studies. His research areas are operations management, quality management and supply chain management. He has papers published or accepted by such journals as Journal of Operations Management, Organization Science, Manufacturing and Service Operations Management, and Production and Operations Management.
} 


\section{Publisher's Note}

Springer Nature remains neutral with regard to jurisdictional claims in published maps and institutional affiliations.

Received: 11 April 2018 Accepted: 14 May 2018

Published online: 22 May 2018

\section{References}

Anderson SW, Daly JD, Johnson MF (1999) Why firms seek ISO 9000 certification: regulatory compliance or competitive advantage? Prod Oper Manag 8:28-43

Boiral O (2007) Corporate greening through ISO 14001: a rational myth? Organ Sci 18:127-146

Brunsson N (1989) The organization of hypocrisy: talk, decisions and actions in organizations. John Wiley \& Sons, Chichester

Brunsson N (2000) Standardization and uniformity. In: A world of standards. Oxford, Oxford Unviersity Press, pp 138-150

Clougherty JA, Grajek M (2014) International standards and international trade: empirical evidence from ISO 9000 diffusion. Int J Ind Organ 36:70-82

Corbett, C. J., Montes-Sancho, M. J., \& Kirsch, D. A. (2005). The financial impact of ISO 9000 certification: An empirical analysis 51(7), 1046-1059

DiMaggio PJ, Powell WW (1983) The iron cage revisited: institutional isomorphism and collective rationality in organizational fields. Am Sociol Rev 48:147-160. https://doi.org/10.2307/2095101

Grossman SJ (1981) The informational role of warranties and private disclosure about product quality. J Law Econ 24: 461-483

Guler I, Guillén MF, Macpherson JM (2002) Global competition, institutions, and the diffusion of organizational practices: the international spread of ISO 9000 quality certificates. Adm Sci Q 47:207-232

Hallak JC (2006) Product quality and the direction of trade. J Int Econ 68:238-265

Heras-Saizarbitoria I, Boiral O (2015) Symbolic adoption of ISO 9000 in small and medium-sized enterprises: the role of internal contingencies. Int Small Bus J 33:299-320

Hudson J, Jones P (2003) International trade in 'quality goods': Signalling problems for developing countries. J Int Dev 15:999-1013

Hummels D, Klenow PJ (2005) The variety and quality of a nation's trade. Am Econ Rev 95(3):704-723

ISO. (2016). The ISO survey of management system standard certifications 2016

Lavissiere A, Rodrigue JP (2017) Free ports: towards a network of trade gateways. J Ship Trade 2(7):1-17

Lo, C. K. Y. and Yeung, A. C. L. (2018). Quality management standards, Institutionalization and Organizational Implications: A Longitudinal Analysis, International Journal of Production Economics, accepted

Meyer, J. W., \& Rowan, B. (1977) Institutionalized organizations: Formal structure as myth and ceremony. Am J Sociol 83(2):340-363.

Munim ZH, Schramm HJ (2018) The impact of port infrastructure and logistics performance on economic growth: the mediating role of seaborne trade. J Ship Trade 3(1):1-19

Oliver C (1991) Strategic responses to institutional processes. Acad Manag Rev 16:145-179

Potoski M, Prakash A (2009) Information asymmetries as trade barriers: ISO 9000 increases international commerce. J Policy Anal Manag 28:221-238

Staw BM, Epstein LD (2000) What bandwagons bring: effects of popular management techniques on corporate performance, reputation, and CEO pay. Adm Sci Q 45:523-556

Terlaak A, King AA (2006) The effect of certification with the ISO 9000 quality management standard: a signaling approach. J Econ Behav Organ 60:579-602

Tybout JR (2000) Manufacturing firms in developing countries: how well do they do, and why? J Econ Lit 38:11-44

Yeung AC, Lo CK, Cheng T (2011) Behind the iron cage: an institutional perspective on ISO 9000 adoption and CEO compensation. Organ Sci 22:1600-1612

Yeung G, Mok V (2005) What are the impacts of implementing ISOs on the competitiveness of manufacturing industry in China? J World Bus 40:139-157

\section{Submit your manuscript to a SpringerOpen ${ }^{\circ}$ journal and benefit from:}

- Convenient online submission

- Rigorous peer review

- Open access: articles freely available online

- High visibility within the field

- Retaining the copyright to your article 